\title{
1. National urban policies in Europe - an introduction
}

\author{
Valeria Fedeli and Karsten Zimmermann
}

\section{INTRODUCTION}

Urban problems are back on the political agenda and several policy documents, such as the New Urban Agenda (UN-Habitat 2016; Caprotti et al. 2017) as well as the Pact of Amsterdam (EU Urban Agenda), call for national urban policies as one of the key measures to implement the goals defined in these documents (UN-Habitat 2015). It is not difficult in this respect to figure out why UN-Habitat and other international actors have invested efforts in trying to define national urban policies as a response to the worldwide dynamic of urbanization (UN-Habitat 2015 and 2014; OECD 2017; Turok and Parnell 2009). In fact, without significant help in terms of financing, but also without appropriate policy knowledge and legal instruments, supported by national governments, cities will hardly be able to implement the goals of the internationally signed urban agenda adopted at the Habitat III conference held in Quito in 2016 or take over the role of 'vectors of change' (Parnell 2016).

The rise of international urban agendas comes along with a notable number of publications on the resurgence of cities and city-regions and the rise of 'The City as a global political actor' (Oosterlynck et al. 2019). Various assumptions are made in this debate about the relationship between cities and nation states. These assumptions range from a newly gained autonomy of cities vis-à-vis weakened national governments ${ }^{1}$ to the selective support of a limited number of cities as national champions (Crouch and Le Galès 2012).

In this edited volume we start from the postulate that all this is less clear and evident than many people perceive and claim. Does the growing relevance of international Urban Agendas translate easily into national urban policies? And if yes, in what way do national governments give priority to urban policies over others? Does the European Union make a difference in this regard? For sure, the debate on urban policies differs slightly between Europe and many other places in the world, as the European Commission, unlike UN-Habitat, has regulatory and financial instruments to implement what is called the urban 
dimension of cohesion policy (Atkinson and Zimmermann 2016; Fedeli et al. 2020; Armondi and De Gregorio Hurtado 2020a). The European Commission has developed over the last decades instruments and funding schemes that are expected to help cities solve urban problems - not only cohesion policies, but also mobility policies (i.e. Sustainable Urban Mobility Plans, SUMP) and environmental regulation (i.e. air pollution, noise reduction) trying to cope with more sectoral objectives, although with an integrated approach. However, most authors agree that the efficacy of the efforts of the European Commission, the Directorate-General for Regional and Urban Policy in particular, still depends very much on the commitment and the corresponding policies of the member states (Atkinson and Zimmermann 2016). EU urban policy relies on a mix of intergovernmental, national and regional initiatives, and the partnership model chosen in the EU Urban Agenda - more a method than a traditional policy programme - can explain why we find quite a few publications on this urban policy (i.e. the urban dimension of EU policy but also explicit policy documents) and comparative reports on its current impact on cities, updating some of the comparative work done during the 1990s (when the policy framework was based more on a logic of pilot projects in different places and further mainstreaming, see van den Berg and van der Meer 2014).

Publications on EU urban policies in fact outnumber those on national urban policies. Given the relevance of the topic, it is indeed surprising that there is no comprehensive and comparative work on the trajectories of the national urban policies of individual European countries (as existed in the 1990s, as a sort of preparation to a more coordinated framework for action to be introduced by the European Union, see van den Berg et al. 1998, 2007 and d'Albergo 2010²). The OECD published an inventory of national urban policies in OECD states in 2017 as a contribution to the implementation of the New Urban Agenda, but the country profiles in this publication are rather short collections of facts and simple evidences which do not account for the broad ongoing debate and contested processes of experimentation within each country (OECD 2017). Other recent publications are less systematic but try to come to grips with the variegated and multi-scalar nature of Urban Agendas (Armondi and De Gregorio Hurtado 2020b).

At the same time, we cannot deny that national urban policies do exist in different forms and have different scopes. The degree of variation is very high, ranging from the French Politique de la Ville to the German Städtebauförderung, the no longer existing Dutch VINEX, and the British 'New Deal for Communities' (2001-2010) or more recent Urban Renaissance (Rae 2013) or national housing policy schemes. Other member states of the European Union do not have explicit urban policies, but consistently implement EU measures (such as URBAN II or Integrated Sustainable Urban Development (ISUD) as part of EU cohesion policy) or are more concerned 
about rural territories. It is also remarkable that some member states as well as the UK had explicit national urban regeneration programmes in the past but abolished them for various reasons (the UK being a case in point) or moved towards more ad hoc and experimental models (e.g. the City Deals in the Netherlands, Dignum et al. 2020). These changes call for explanations. Was a specific type of redistributive National Urban Regeneration Policy (or city welfare) a temporary phenomenon of the post-war Keynesian welfare state? And what comes next? What kind of national urban policy emerges in increasingly decentralized settings in times of austerity? Or is national urban policy an obsolete model, with inefficient tools and too ambitious expectations? Are cities destined to take the lead and react on their own? Are they still an issue in national politics and how is the structural change in political landscapes affecting the traditional ways in which policy-makers have included the urban in their agenda?

In this book we invited a group of urban scholars to write, in a comparative perspective, about the trajectories, instruments, goals and eventual impacts of national urban policies in their countries. Taking a long-term perspective on the evolution of national urban policies, our main interest is the persistence, convergence or divergence of national urban policies. We also wanted to know if there are political struggles surrounding the scope and direction of national urban policies. And, last but not least, we wanted to know what the impacts of EU policies are, and in particular how these will affect the next EU funding period (i.e. 2021-2027).

\section{DEFINING NATIONAL URBAN POLICY}

National urban policy is difficult to categorize as, at a certain level of abstraction, all public policies are in a way urban, at least in highly urbanized countries (DeFilippis 2016, p. 4). One strategy to overcome this dilemma would be to define national urban policy in the way governments do it. Hence, we would consider 'urban' all the policies that are initiated by ministries or governmental agencies dedicated to urban issues, ultimately striving for a coordinated and comprehensive strategy for urban development. In fact, in some states, ministries or state agencies on the national level have existed, or still exist, that had, or still have, the word 'urban' in their title. The 'White House Office for Urban Affairs' during the time of the Obama administration is a case in point (DeFilippis 2016, p. 2). Another example would be the French Agence Nationale pour la Rénovation Urbaine (ANRU). In Germany this is currently not the case, but in the past there were ministries that, while only partly responsible for urban issues, were so in a more explicit way. In more recent times, one can find attempts to define national urban policy in a programmatic way in international policy settings but less so on the national level. According to 
UN-Habitat, for example, a national urban policy is: 'A coherent set of decisions derived through a deliberate government-led process of coordinating and rallying various actors for a common vision and goal that will promote more transformative, productive, inclusive and resilient urban development for the long term' (UN-Habitat 2015, p. 14).

In this rather broad (and normative) definition quite a few elements are missing such as financing of local governments (or fiscal relations between different state levels) and sectoral policies such as transport policies, social policies, housing policies and urban regeneration policies. In addition, despite the fact that a simple definition such as 'national urban policy is what governments or international organizations call national urban policy' would be a very positivistic view on the issue, the overview taken in this volume shows that in many countries a highly profiled national urban policy does not exist. Still, the absence of clearly stated urban policies does not imply that governments do not support cities effectively through sectoral programmes for housing or transport, or any other policy that has an impact at the urban level. In other cases, governments may declare that urban agendas are relevant, but implementation then proves cumbersome. The result is that there is epistemic uncertainty regarding what the unit of analysis is. This can result in a relevant policy problem, but can also make clear how this policy field is place-based and situated, notwithstanding the widespread belief in international urbanism as a place-less and globalized practice. Even though the urban seems to be more of a planetary issue (Brenner 2013), our ideas of cities and the societal issues related to them are very much place-based and path-dependent. Is this place-based and path-dependent boundedness a resource or a trap for the elaboration of public policies? How can national urban policies help cities tackle urban problems that have their origin in international connectivity? Still, the impact of globalization on the one hand, and planetary urbanization on the other, does not seem to be properly reflected in the elaboration of urban agendas (the New Urban Agenda of the UN being an exception). So much so that the national scale still seems to matter, if not for its future impact then at least for the burden of the legacies of the past.

Rather than giving cities an active role in the 'Great Transformation' (WBGU 2016) or considering them as 'vectors of change' in the context of the implementation of the New Urban Agenda (Parnell 2016), we take a more systemic and explanatory approach on the emergence, evolution and eventual disappearance of national urban policies. Hence, we are looking for explicit urban policies addressing (at least in a declaratory way) urban problems. Still, we need to answer the question: how broadly (or narrowly) do we want to define national urban policy? Is a national urban policy any national response to common urban challenges? Do we only consider coherent and targeted policies, or do we also take into account initiatives that are not 'urban' but have 
an indirect impact on cities (i.e. modernization of public administration, introduction of New Public Management)? In the scholarly literature, systematic attempts to define national urban policy are rare. Many publications are about specific aspects of urban policies (such as housing or urban regeneration). Others see national urban policies through the lens of governmentality, questioning in a more fundamental way how urban problems and their respective solutions are constructed and framed by governments (see Dikeç 2007 for the case of the French Politique de la Ville as a reaction to the 'problems' of the banlieues). Only a few volumes analyse the politics behind the invention of national urban programmes (DeFilippis 2016 and Gelli 2012 for the case of the US; Cole and Payre 2016 for a more theoretical contribution). In addition, we need to think about the selectivity of national urban policies. Some governments give specific support for capital city regions or create programmes that benefit a small number of big cities. There is a growing interest in the differentiation of policies in relation to the manifold forms the urban is taking in the contemporary world.

Tortola (2013), in a US-European comparison, speaks of City Welfare as a subset of urban policies. He describes City Welfare as 'the use of fiscal resources to promote the well-being of cities qua cities, namely intervening on all or at least a combination of their various social, economic, and physical aspects' (Tortola 2013, p. 651). City Welfare is explicitly focused on places rather than persons and on a distributive or redistributive policy (instead of a regulatory policy). In addition, Tortola distinguishes between the policy dimension and the politico-institutional dimension. While the policy dimension is about programmes and instruments that are implemented in decentralized or centralized settings, the politico-institutional dimension refers to the extent to which City Welfare is rooted in the government (i.e. finds institutional or political support). For our purposes, City Welfare is a too narrow way of defining national urban policy as there are many other policy dimensions to consider (climate change and adaptation, mobility, innovation, land use and environmental aspects, culture). Nevertheless, we cannot avoid reflecting on how national urban policies are increasingly stressed by the limits and failures, or even the crises, of city welfare systems that were essentially built after the two World Wars and now definitely need a restructuring process, if not a thorough reinvention.

Van den Berg et al. (2007, p. 1) defined national urban policy in the following way: "National urban policy" refers to policies that affect the cities knowingly and directly.' However, in the same volume they consider indirect policies affecting cities also as national urban policy (ibid. p. 4). This distinction between direct and indirect urban policies is very relevant as it demarcates whether governments give priority to cities or not (see below). In addition, and referring in advance to the content of some of the chapters 
of this volume, in federal and regionalized states national urban policies are both shared and separated between levels at the same time. In order to ensure comparability, we suggest a more systemic definition of national urban policy (see d'Albergo 2010), namely a national urban policy is any national policy or programme explicitly targeted at urban areas. Obvious examples are social housing policies, urban regeneration programmes, planning policies and urban mobility policies (but not necessarily decentralization measures, tax policies or public financing). This includes funding mechanisms, but also strategic or programmatic documents that give guidance on what is understood as good urban policy. We may also consider national policies that take cities to be an important means for implementing national policy goals (such as sustainable energy provision, mitigation of climate change or coping with migration). What would be interesting in this respect would be to observe if and how the field has been characterized by the reinvention of sectoral policies that had been invented almost a century ago, if not before.

Against this background, an article by Ernesto d'Albergo (2010) is helpful. He distinguished between direct and indirect and explicit and implicit national urban policies (see Figure 1.1) and defined them as follows:

- Direct: any national policy intervention directly tackling urban problems through funding or legislation (including binding goals).

- Indirect: any provision of resources (subsidies, knowledge, instruments) or programming of conditions that helps local governments solve urban problems.

- Explicit: policies that have an urban or territorial focus.

- Implicit: any other policy.

We consider this typology to be a helpful heuristic. In particular, distinguishing between direct and indirect urban policies is a necessary step when systematizing national answers to urban challenges. But the purpose of this book is broader, taking into consideration the dimension of actors and the evolution of national urban policies over time. Hence, the contributions strive for more explanatory approaches and take into consideration the relationship between the state and local governments. When it comes to explanations for the evolution of national urban policy, some of the factors mentioned in the literature are rather functionalist. For sure, in some countries the degree of urbanization, the number of large cities and the emergence of typical urban problems (such as urban decline, traffic congestion) have an impact on the evolution of national urban policies (van den Berg et al. 2007, p. 400). But the fact that in some countries in Europe urban problems have existed for several decades without any proper or strategic reaction by national governments puts these explanations into question. 


\begin{tabular}{|c|c|c|}
\hline & $\begin{array}{c}\text { Explicit } \\
\text { (with an Urban Spatial Focus) }\end{array}$ & $\begin{array}{l}\text { Implicit } \\
\text { (without an Urban Spatial Focus) }\end{array}$ \\
\hline $\begin{array}{l}\text { Direct } \\
\text { (aimed at directly } \\
\text { tackling urban } \\
\text { challenges) }\end{array}$ & $\begin{array}{l}\text { area-based programmes } \\
\text { - } \text { for economic growth } \\
\text { (UK, France) } \\
\text { - } \text { for social inclusion } \\
\text { (UK, France, Germany) } \\
\text { - } \text { for security } \\
\text { (UK, France) }\end{array}$ & $\begin{array}{l}\text { mainstream policies } \\
\text { (all the four countries) }\end{array}$ \\
\hline $\begin{array}{c}\text { Indirect } \\
\text { (aimed at providing } \\
\text { others with conditions } \\
\text { for tackling urban } \\
\text { challenges) }\end{array}$ & $\begin{array}{l}\text { policies for the re-spatialization of } \\
\text { urban (local) government } \\
\text { (UK, France) }\end{array}$ & \begin{tabular}{|l} 
policies for institutional innovation \\
$-\quad$ decentralization of power and \\
multilevel relationship \\
(UK, France, Spain) \\
$-\quad$ reforms of local government \\
(UK, Spain) \\
$-\quad \begin{array}{l}\text { reforms of structures and processes } \\
\text { of public action } \\
\text { (UK, France) }\end{array}$
\end{tabular} \\
\hline
\end{tabular}

Source: d'Albergo (2010, p. 140).

\section{Figure 1.1 A typology of national urban policies}

As clearly demonstrated by d'Albergo, the political system eventually has an impact. The difference between federal and non-federal states, the administrative and political strength of local governments and the type of welfare state are promising factors for explaining variation. In residual welfare states, as well as in federal states, national urban initiatives are supposed to have a low profile. However, particularly with regard to the role of social democratic welfare states in the evolution of city welfare policies, the study of Sellers and Lidström (2007) is instructive. They found evidence that it is not a strong social democratic welfare state that allows local governments to implement high-profile city welfare schemes; rather, strong local governments are a prerequisite for national welfare states. This points to the need to take a historical perspective when analysing national urban policies (Cole and Payre 2016), and the authors of this volume have been asked to provide such a perspective on the current situation.

\section{WHAT IS THE STATE OF THE ART?}

In an introduction the reader would normally expect a concise summary of the academic debate. With regard to national urban policies this task is not easy to accomplish. There is no lack of publications on national policies that are relevant for cities (urban regeneration, housing, social policies), but these 
studies do not interpret these programmes as a national urban policy. There are a few that try to elaborate the mechanisms, instruments and politics of national urban policies (see for example the role of Urban@it in Italy), but in the main they concentrate on a single country (Béal et al. 2018). Therefore, evidently there is a lack of systemic comparative work. The two volumes of van den Berg are an exception to this. Van den Berg et al. $(1998,2007)$ presented two collections of 15 national reports and emphasized the common challenges of urban development in Europe. The first volume was written and edited in the context of the continuing European integration process in the second half of the 1990s. This was a period when the European Spatial Development Perspective (ESDP) was approved and a European urban policy took shape (Atkinson 2001). The deepening of the European integration process as well as the expected enlargement gave these documents a forward-looking undertone. In fact, the volume published in 1998 came to the conclusion that more and more governments of EU member states were willing to give cities an active role in regional and national development (van den Berg et al. 2007, p. 23). The second edition came to a similar conclusion. Today we can say that, although $\mathrm{UN}$ and EU sources speak of a resurgent cycle of national urban policy, the situation is more confusing, as we observe a variety of initiatives and policy struggles (smart cities, austerity urbanism, decentralization, climate change and management of risks). Some of these initiatives are temporary in nature, hence it is questionable whether they constitute or contribute to a national urban policy. The general political situation as regards the EU integration process has changed significantly. Hence, this volume differs from the books presented by van den Berg et al. $(1998,2007)$ in the way that national urban policies are looked at, and we also put much less emphasis on Europeanization. What is more, both volumes of van den Berg et al. $(1998,2007)$ are inventories and present rich insights into the state of common urban challenges in Europe, but they give only limited emphasis to the policy and politics dimension. The chapters collected here, on the contrary, try to deal with this relevant issue.

\section{QUESTIONS AND DIRECTIONS FOR FUTURE RESEARCH}

In order to give our debate a minimum of structure we suggested the authors use the well-known differentiation between policy, polity and politics that serves well for descriptive, analytical and comparative purposes (Heinelt 2017). In the following, we define the three dimensions more precisely for our purpose, reformulating them as questions. ${ }^{3}$ 
Politics: The politics dimension refers to the stance of stake- and interest-holders and the political process, conflict and power struggles. Guiding questions are:

- Why should there be a national interest in urban matters in the first place when it could be argued that such matters should instead be entirely the responsibility of units of local and regional self-government? Does this imply that the state interferes with self-governing units and, if so, how?

- Can we say that the global energy turn (low-emission buildings and districts) as well as $\mathrm{CO}_{2}$ reduction is having a new, powerful impact on the formulation of national urban policy? Are the sustainable development goals, in the perspective of the Anthropocene, bringing in a new relevance?

- Are there emerging transnational and translocal issues that are being intercepted by national urban policies, and are national governments able to react to these?

- What are the current goals of national governments when tackling urban issues?

- What role is played by local interest organizations, such as the national associations of local authorities? Are these networks still relevant, and to what extent are they able to restructure the policy agenda? Are they bringing in new spatial imaginaries and policy ideas?

- Which types of 'urban' areas are targeted in these policies - cities (only the largest ones or also medium-sized towns), city-regions as a whole or specific targeted areas (inner-city, troubled suburbs, etc). Is specific attention being paid to the way in which the urban is changing and, if so, does this attention have a clear relationship with the current restructuring of political parties and movements?

- What are the party-political conflicts and perspectives on urban policy? Is there any connection between political change and the role cities have in the political debate?

Policy: The policy dimension refers to sectoral programmes (housing, transport and mobility, social policies and cohesion, economic development) and includes instruments as well as governance and the policy-making process (goals, actors).

Among different policy areas, it would be useful to distinguish between policies that aim at improving the general capacity of the urban area (traffic investments, housing development, commuting facilities, environmental protection but also through institutionalization of metropolitan governance arrangements) and those that have a more redistributive function (such as supporting development in segregated areas, facilitating integration of people with foreign origin and intra-metropolitan distribution of resources). A distinction can also be made between policies regarding cities as a problem (segregation, 
congestion, inequalities, etc.) and policies seeing them as a solution (forerunners for development in the rest of the country or internationally, hubs of international competition and of innovation, etc).

Some policies may be interventionist, having a direct effect, whereas others are more indirect, providing preconditions rather than interventions (see above). Hence a number of questions arise:

- Is there a conceptual background of national urban policies? Are there countries which have tried to develop a strategic vision?

- Is national urban policy characterized by the use of specific steering mechanisms (such as regulation, financial incentives, information campaigns)? What is the role of national financial equalization schemes in urban areas? Is there any reflection available on the efficacy of previous experimentations which can provide insights on current policy challenges?

- Are urban policies seen as being an essential part of metropolitan policies? Does the integration of the broader functional areas of the biggest agglomerations find support through ways of encouraging coordination, cooperation in the area of service delivery and sustainable spatial planning (effects of sub-urbanization) as well as of promoting economic development?

Polity: Polity has to do with the constitutional dimension, taking into consideration the discursive turn that raised the attention on polity as a socio-political construct. In this dimension, the questions to be addressed relate to how and to what extent urban policies play a role in this process of socio-political construction and how, on the contrary, the institutional context shapes urban policies. Questions include:

- How are national urban policies institutionalized at central government level? Are there any specific authorities? Are there any specific institutions, norms, legislative aspects or is there a legal status for local self-government at all?

- Are national urban policies an open field of experimentation into both the governance challenges and the very idea of public policies? Are, in other words, national urban policies a recognized field of innovation where innovators find support and acceptance?

- Within the EU debate and framework, does the field of urban policies as interpreted at the national level reflect the push for innovations at the polity level? 


\section{THE CONTRIBUTIONS OF THIS BOOK}

As anticipated, there are next to no up-to-date overviews of national urban policies in the scholarly literature. Only a few collections or edited volumes on national urban policies exist, the two volumes of van den Berg et al. (1998, 2007) being an exceptional collection that points to common urban challenges in Europe and emerging EU urban initiatives. The OECD (2017) published a report with rather short descriptions of national urban policy in OECD countries, and Armondi and De Gregorio Hurtado (2020b) edited a volume discussing specific aspects of national urban agendas. The contributions in this book give more emphasis to national discourses, the political struggles concerning the often troublesome implementation of national urban policies, but also the instruments that are in use (Béal et al. 2018). Given the diversity of urban policies and priorities given to cities by national governments, we will give less emphasis to common challenges in the European Union as an eventual basis for urban agendas, instead providing an overview on the evolution of national urban policies and agendas and their prospects.

The book covers Spain, Portugal, Germany, Poland, Norway, Sweden, France, the UK, Ireland, the Netherlands, Slovakia, Italy and Romania. It is the result of an initiative that emerged from the annual conferences in 2018 and 2019 of the European Urban Research Association, which led to the creation of a Working Group whose work forms the basis of this book. The main aim of such initiatives is to promote research spaces that operate without any additional funding but build on existing research experiences and the intrinsic motivation of scholars. The advantage of the approach taken by this book is that the contributions of different colleagues better reflect the local debate, as well as the different theoretical orientations of each contributor. This may generate greater inconsistency compared to a traditional book published on the back of the results of a research project. Nevertheless, the freshness and originality of each chapter, as an outcome of the situatedness of each author in his/ her own country, is, in our view, a unique and useful resource for the reader. Although each chapter followed the conceptual framework as suggested in this chapter, every contribution also opens up other possible ways to explore national urban policies. We believe this is a crucial starting point for further and more systematic policy-oriented research. The book in this respect fulfils one of the main aims of EURA, an interdisciplinary and international research association born in the late 1990s with the objective of promoting an open and constructive dialogue between theory and practice. We hope this book can provide our colleagues from different disciplinary fields looking at urban policies interesting facets of urban policy for further reflection and for feeding 
new research projects dealing with the many open questions and dilemmas this book highlights.

\section{NOTES}

1. See also the agenda of the recently established DFG research unit 2757 on 'Local self-governance in the context of weak statehood in antiquity and the modern era', https://www.uni-wuerzburg.de/for2757/losam/.

2. Van den Berg et al. (1998 and 2007) describe national responses to urban challenges in 15 EU member states. D'Albergo (2010) seeks to develop a typology of national urban policy based on insights from Spain, Germany, France and the UK.

3. We are grateful to Anders Lidström, Maroš Finka, Piotr Zuber, Juliet Carpenter and Sonia De Gregorio Hurtado.

\section{REFERENCES}

Armondi, S. and De Gregorio Hurtado, S. (2020a), Introduction. Making sense of the urban agendas: studies in the production and use of the urban in agenda discourses, in: S. Armondi and S. De Gregorio Hurtado (eds), Foregrounding Urban Agendas: The New Urban Issue in European Experiences of Policy-Making. Cham, Switzerland: Springer, pp. v-x.

Armondi, S. and De Gregorio Hurtado, S. (eds) (2020b), Foregrounding Urban Agendas: The New Urban Issue in European Experiences of Policy-Making. Cham, Switzerland: Springer.

Atkinson, R. (2001), The emerging 'Urban Agenda' and the European spatial development perspective: towards an EU urban policy?, European Planning Studies, 9(3), 385-406.

Atkinson, R. and Zimmermann, K. (2016), Cohesion policy and cities: an ambivalent relationship, in: Simona Piattoni and Laura Polverari (eds), Handbook on Cohesion Policy in the EU. Cheltenham, UK and Northampton, MA, USA: Edward Elgar Publishing, pp. 413-426.

Béal, V., Epstein, R. and Pinson, G. (2018), Networked cities and steering states: urban policy circulations and the reshaping of state-cities relationships in France, Environment and Planning C: Politics and Space, 36(5), 796-815.

Brenner, N. (ed.) (2013), Implosions/Explosions: Towards a Study of Planetary Urbanization, Berlin: Jovis.

Caprotti, F., Cowley, R., Datta, A., Castán Broto, V., Gao, E., Georgeson, L., Herrick, C., Odendaal, N. and Joss, S. (2017), The New Urban Agenda: key opportunities and challenges for policy and practice, Urban Research and Practice, 10(3), 367-378.

Cole, A. and Payre, R. (eds) (2016), Cities as Political Objects, Cheltenham, UK and Northampton, MA, USA: Edward Elgar Publishing.

Crouch, C. and Le Galès, P. (2012), Cities as national champions, Journal of European Public Policy, 19(3), 405-419.

D'Albergo, E. (2010), Urban issues in nation-state agendas: a comparison in Western Europe, Urban Research and Practice, 3(2), 138-158.

DeFilippis, J. (ed.) (2016), Urban Policy in the Time of Obama. Minneapolis, MN: University of Minnesota Press. 
Dignum, M., Hamers, D. and Evers, D. (2020), Learning through collaboration: the case of city deals in the Netherlands, in: L. van den Dool (ed.), Strategies for Urban Network Learning. Palgrave Studies in Sub-National Governance. Cham, Switzerland: Palgrave Macmillan, pp. 123-152.

Dikeç, M. (2007), Badlands of the Republic Space, Politics and Urban Policy. Malden, MA: Blackwell.

Fedeli, V., Lenzi, C., Briata, P. and Pedrazzini, L. (2020), EU Regional and Urban Policy: Innovation and Experiences from the 2014-2020 Programming Period, Cham, Switzerland: Springer.

Gelli, F. (2012), La città nella scienza politica americana. Soveria Mannelli, Italy: Rubbettino.

Heinelt, H. (2017), Do policies determine politics?, in: F. Fischer, G. J. Miller and M. S. Sidney (eds), Handbook of Public Policy Analysis: Theory, Politics and Methods. New York: Routledge, pp. 109-122.

OECD (2017), National Urban Policy in OECD Countries. Paris: OECD Publishing.

Oosterlynck, S., Beeckmans, L., Bassens, D., Derudder, B., Segaert, B. and Braeckmans, L. (eds) (2019), The City as a Global Political Actor. London: Routledge.

Parnell, S. (2016), Defining a global urban development agenda, World Development, 78, 529-540.

Rae, A. (2013), English urban policy and the return to the city: a decade of growth, 2001-2011, Cities, 32, 94-101.

Sellers, J. M. and Lidström, A. (2007), Decentralization, local government, and the welfare state, Governance, 20(4), 609-632.

Tortola, P. D. (2013), Federalism, the state, and the city: explaining 'city welfare' in the United States and the European Union, Publius: The Journal of Federalism, 43(4), 648-675.

Turok, I. and Parnell, S. (2009), Reshaping cities, rebuilding nations: the role of national urban policies, Urban Forum, 20(2), 157-174.

UN-Habitat (2014), Evolution of National Urban Policies: A Global Overview. Nairobi: UN-Habitat.

UN-Habitat (2015), National Urban Policy: A Guiding Framework. Nairobi: UN-Habitat.

UN-Habitat (2016), New Urban Agenda. Nairobi/Quito. https://uploads.habitat3.org/ hb3/NUA-English.pdf, accessed 19 January 2021.

van den Berg, L., Braun, E. and van der Meer, J. (eds) (1998), National Urban Policies in the European Union: Responses to Urban Issues in the Fifteen Member States. Aldershot, UK: Ashgate.

van den Berg, L., Braun, E. and van der Meer, J. (eds) (2007), National Policy Responses to Urban Challenges in Europe. Aldershot, UK: Ashgate.

van den Berg, L. and van der Meer, J. (2014), Cities as Engines of Sustainable Competitiveness: European Urban Policy in Practice. London: Routledge.

WBGU (German Advisory Council on Global Change) (2016), Humanity on the Move: Unlocking the Transformative Power of Cities - Summary. Berlin: WBGU. 